\title{
A COMPARATIVE UNDERSTANDING OF CRIMINAL LIABILITY FORMATION FOR CRIMES AGAINST WOMEN IN UZBEKISTAN AND CAMEROON
}

UNA COMPRENSIÓN COMPARADA DE LA FORMACIÓN DE RESPONSABILIDAD PENAL POR DELITOS CONTRA LAS MUJERES EN UZBEKISTÁN Y CAMERÚN

\author{
Dilbar J. Suyunova* \\ Yana Yu. Koniushenko** \\ Nana Charles Nguindip ${ }^{* * *}$
}

\begin{abstract}
Women continue to be victims of violence and the violation of their human rights keep being in the increase as they experienced constant hatred on their status. This article analyzes liability for crimes against women under criminal legislations of the Republic of Uzbekistan and Cameroon by assessing the Criminal Codes rules in both countries in terms of identifying its distinctive features of legal regulation conditional to gender and family differences of subjects is provided. Expert study of criminal legislations related to crimes against women plays a facilitating role in identifying not only real scope of criminal law rules, but also determining if there is a gap in law, or legal regulation is insufficiently socially conditioned. Moreover, analysis of genesis of criminal standards on responsibility for crimes against women made it possible to trace changes in law in relation to
\end{abstract}

\footnotetext{
* Doctor of Science of Law. Professor of the Department of Criminal Procedural Law at Tashkent State University of Law (Tashkent, Uzbekistan). https://orcid.org/0000-00031039-4069. dilbarsuyunova9@gmail.com

** Doctor of Law. Associate Professor of the Department of Criminal Process of the National Academy of Internal Affairs (Kiev, Ukraine). https://orcid.org/0000-0003-4988-0793. vizirmasha@i.ua

*** Senior Lecturer in Law. Department of English Law of the Faculty of Law and Political Sciences of the University of Dschang (Dschang, Cameroon). https://orcid.org/0000-00026333-3983. seniorlecturer84@gmail.com
} 
such objects of criminal law protection as, for example, life, health, sexual freedom and sexual immunity, honor and dignity of woman, interests of family and its members.

Keywords: Crimes Against Women, Criminal Legislation, Domestic Violence, Health of Women, Subjects of Criminal Matters

Resumen: Las mujeres siguen siendo víctimas de violencia, mientras que la violación de sus derechos humanos sigue aumentando a medida que experimentan un odio constante por su condición. Este artículo analiza la responsabilidad por delitos contra la mujer en virtud de las legislaciones de la República de Uzbekistán y Camerún mediante la evaluación de las normas de los códigos penales de ambos países, con el objetivo de identificar sus características distintivas en base a las diferencias de género y familiares de los sujetos. El estudio de expertos de las legislaciones penales relacionadas con los delitos contra la mujer juega un papel facilitador para identificar no solo el alcance real de las normas del Derecho Penal, sino también para determinar si existe una brecha en la ley, o bien la regulación legal no está suficientemente condicionada a nivel social. Además, el análisis de la génesis de las normas penales sobre responsabilidad por delitos contra la mujer permitió rastrear cambios legales en relación con objetos de protección del Derecho Penal como, por ejemplo, la vida, la salud, la libertad e inmunidad sexual, el honor y la dignidad de las mujeres, intereses de la familia y sus miembros.

Palabras clave: Delitos contra la mujer, legislación penal, violencia doméstica, salud de las mujeres, sujetos de materia penal

Summary. I. Introduction. I.1. Purpose and Objectives of Research. I.2. Research Methods. I.3. Research Results. II. Assessment. III. What Type of Crimes Against Person the Crimes Against Women Have Relation To? IV. Cameroon Penal Code and Crimes Against Women. V. Examination of Some of the Offences of Violence on Women Under the Cameroon Penal Code. V.1. Assault Occasioning Death. V.2. Assault Occasioning Grievous Harm. V.3. The Situation of Simple and Slight Harm Caused on the Woman. V.4. Assault on Woman with Child. VI. Women Violence Is Not Prosecuted Under the Cameroon Criminal Law. VII. Woman as an Object of Crimes Against Family, Youth and Morality. VIII. Conclusion. References. 


\section{INTRODUCTION}

The question of necessity to study criminal responsibility for crimes against women, subject to its specificity, did not arise immediately, since, unlike other branches of law such as labor law or family law, the criminal law is not a daily use one, and is applied only when committing a socially dangerous acts (crimes), including against women. In addition, fundamental international legal documents, such as Convention on the Elimination of All Forms of Discrimination against Women (1979), which Uzbekistan joined in 1995, has no reference to public relations, which are the subject of criminal law.

Thus, the Convention binds States parties over to take necessary measures to eliminate discrimination in political and public life, as well as education field, labor and matrimonial relations, but it does not address the issues of preventing discrimination against women specifically in the sphere of criminal law. Merely article 6 of the Convention addresses the issue of crimes against women and establishes that States parties shall take all appropriate measures, including legislation, to suppress all forms of traffic in women and exploitation of prostitution of women. In addition, according to paragraph $a$ ) of the second part of article 11, the Convention prohibits, under threat of a sanction, dismissals from work based on pregnancy or maternity leave. The experience of legal counteraction to domestic violence in European countries and the provisions of the United Nations model law on combating these types of violence can serve as a serious legal basis for the development of domestic law and law-enforcement practice (Lehenka, 2018).

\section{I.1. Purpose and Objectives of Research}

Purpose and objectives of research is to develop proposals and recommendations aimed at further improving criminal legislation regarding responsibility for crimes against women in both Uzbekistan and Cameroon when issues of women crimes are concerned.

Research on formation and development of criminal legislation of Uzbekistan and Cameroon in terms of crimes against women, research of elements of crime that are committed against women, comparative analysis of some crimes against women in the Criminal Code of Uzbekistan and Cameroon, rationale for amendment of some articles of the Criminal Code of Uzbekistan and Cameroon where victim is a woman, development of proposals for improvement of national criminal legislation in order to protect the rights and interests of women. Developing a concrete research objective will be fundamental cement in seeing the need of ensuring women right 
standard. As a potential actor in international law, the State of Uzbekistan and Cameroon must be able in ensuring effective women right protection.

\section{I.2. Research Methods}

As part of the research, general scientific and special methods of scientific knowledge were used: historical, systematic, comparative legal, analytical, logical-legal and others, that made it possible to a certain extent to ensure reliability and validity of results of this research.

\section{I.3. Research Results}

The paper makes a historical analysis of criminal legislation rules relating to crimes against women, provides comparative review of some types of criminal liability for crimes against women in CIS and non-CIS countries, demonstrates the need to amend existing articles of the Criminal Code that calls for responsibility for crimes against women, proposes improving the criminal legislation of Uzbekistan and Cameroon, in terms of responsibility for crimes against women.

\section{ASSESSMENT}

When there are sufficient grounds to believe that domestic violence is systematic, the use of prior administrative response procedures should be avoided after the first report or personal detection by the police officer (Orlov, 2020). Assessment of rules of criminal legislation in terms of peculiarities of its legal regulation is conditional to gender differences of subjects and objects of elements of crime. This analysis has shown that during certain period of formation and development of independent Uzbekistan, rules of criminal legislation concerning liability for crimes against women have also changed. History of criminal legislation allows us to trace changes in public legal consciousness in relation to objects of criminal law protection, among which life, health, sexual freedom, honor and dignity of women, interests of family and its members can be indicated.

In ancient Uzbekistan (1884-1917), at the time of Sharia, attitude towards women was more than humiliating. Parents considered the girl as an «extra mouth» in the family, and from the moment of her birth they thought about her "arrangement" and looked for a suitor for one-year-old baby. Girl being in the cradle was the property of another person who bought her from her parents according to customary sale and purchase transaction: kalym (repurchase), which was illustrative of slave position of women in 
society. Woman was bought and sold for money, no one regarded her opinion.

According to the rule of Sharia - "fear your husband after God"woman was the property of her husband, who derived full power over her, could punish for the slightest disobedience continuing until battery legal. Herewith, according to Sharia, husband was not responsible for abuse of his wife. A beaten and crippled woman could formally complain about her husband, but no one listened to her or supported her. The Kazi (judge) always took the side of her husband, since he received money from him, and besides by himself, as a man, lived according to Sharia.

At the same time, man had every right to marry again, since the Sharia allowed polygamy, while husbands used a whip against disobedient, obstinate wives, since the Sharia enacted "strictness in treatment of wives".

Later (1917-1991) place of women changed, their emancipation took place and women began to take part in elections to local councils, while law codified their rights to labor, education, medical care, pensions and others. Structure of executive branch formed women's departments, which assisted women, took measures to provide them with work, and protected them from despotic husbands. It was during this period that Uzbekistan adopted the Marriage and Family Code, the Civil Code, the Criminal Code and other legislative acts regulating rights and freedoms of women, including their protection from criminal infringements.

\section{WHAT TYPE OF CRIMES AGAINST PERSON THE CRIMES AGAINST WOMEN HAVE RELATION TO?}

Criminal legislation of many countries places special emphasis on problems related to domestic violence. The Family Code of the Republic of Uzbekistan enshrines equality of women and men in family relations (Article 2) and emphasizes that "all citizens have equal rights in family relations" (Article 3), "spouses enjoy equal rights and bear equal responsibilities" (Article 19). At the same time, established practice in applying the law still encounters cases of violation of these rights, which leads to domestic violence against women.

Issue of domestic violence has long been taboo all over the world, and any attempts to develop and lobby a law on its adoption were perceived as negative Western influence. Stereotypes reflected in mentality of many nations justified the situation of violence, and it stopped perceiving as it is. Attitude towards it for the most part has become commonplace, natural. And it increasingly becomes a common type of offense that trenches upon life, 
health and dignity of women and children. According to statistics, most murders, inflictions of bodily harm of varying degrees of severity, beatings and humiliations, coercion into early marriages, crimes for sexual reasons are committed in family on domestic grounds. Today it is no coincidence that programs practicing targeted deterrent model to reduce various forms of violence (Morgan, et al., 2020) have growing support abroad.

Domestic abuse issues today during the coronavirus pandemic become more pronounced. Many scientists around the world are discussing danger of COVID-19 not only in terms of health, but also in terms of atmosphere in the family, when all its members are at home, and the likelihood of violence arises. As Katrin Kaukinen (2020) rightly noted, "Coronavirus pandemic will have an unprecedented impact on frequency and consequences of crime and violence around the world. This includes influencing the risk, consequences and decision-making of women experiencing intimate partner violence". Recent article by Amanda Taub (2020) suggests "travel restrictions intended to stop the spread of coronavirus could make domestic violence more frequent, more violent and dangerous".

Peculiarity of these crimes is that the weakest members of family become the target of violence. As well as the fact that most of these crimes have latent, i.e., insidious nature, when due to fear of husband (father) or due to family obligations, traditions, religious beliefs, material and other dependences, the victims do not report to the law enforcement agencies about acts of violence committing or committed against them.

Many changes have taken place in Uzbekistan with adoption of the Law of the Republic of Uzbekistan On the Protection of Women from Oppression and Violence on 17 August 2019, which aims to regulate relations in the field of protecting women from all forms of oppression and violence. It is thought that adoption of such important law on protection of women's rights, their protection from violence, will contribute to introduction of appropriate amendments to the Criminal Code of following nature.

Section one of the Criminal Code provides for liability for crimes against person, where, in case of intentional homicide (Part 2, Article 97), incitement to suicide (Article 103), inducement to suicide (Article 103), intentional grave bodily injury (Article 104), intentional moderate bodily injury (Article 105), intentional slight bodily injury (Article 109), torture (Article 110), threat of homicide or violent use (Article 112), a victim of criminal acts is a person without gender determination, with the exception of "women known to perpetrator was pregnant" distinctive feature. In other words, most rules of criminal liability apply to both women and men.

Taking into consideration Uzbekistan's topical issues on development of legislative frameworks for combating domestic violence, we presume to 
include a distinctive feature into indicated elements of crime against person that will provide for liability of "spouse or person in extramarital relationship with perpetrator". It should be noted that similar liability is provided by the Criminal Code of France (in all crimes of intentional infringements of inviolability of person, spouse or person in extramarital cohabitation with victim committed such a crime is brought to justice), and the Criminal Code of Belgium (Articles 398-405 — crimes of murder that are not qualified and of intentional harm to health, where perpetrator committed such acts against his spouse or person with whom he cohabits or cohabited, maintains or maintained long-term love and sexual relations).

The Turkish Criminal Code provides for liability for crimes against life committed against "wife, husband, brother, sister, adoptive parents, adopted son, adopted daughter, stepmother, stepfather, stepson, stepdaughter, father-in-law (both father of wife and father of husband), mother-in-law (both mother of wife and mother of husband), son-in-law or daughter-in-law" (Article 449). Chapter 4 of the Criminal Code provides for liability for sexual assault and indecent assault. In order to protect women from criminal infringements, attention should be paid to two elements of crime in this chapter: assault (Article 118) and forcible satisfaction of sexual need in unnatural form, forcible sodomy (Article 119).

Assault (forcible rape) is one of the most serious violent crimes against women. As evidenced by data of criminal statistics, Uzbekistan registered rise in number of assaults until 2014 inclusive, while in the period 20152019 figures in records for this crime began to decline. Indeed, if 2014 registered 635 assaults in the country, 2019 showed 204 similar crimes (State Statistics Committee of the Republic of Uzbekistan, 2019). Such dynamics can be explained both by large-scale crime prevention works carried out in the Republic of Uzbekistan, and by high latency of this crime due to the fact that many victims of assault do not apply to law enforcement agencies.

Analysis of criminal legislation on this type of crime has shown that historically assault has always been referred to serious crimes, while existence of aggravating circumstances was especially serious crime. According to edition 1959 of the Criminal Code, liability for simple and aggravated assault is punished by three up to seven years' imprisonment and by eight to fifteen years imprisonment or by death penalty. In accordance with amendments to the Criminal Code introduced by Law in 2001, current Criminal Code imposes punishment for assault with distinctive features from seven to ten years (Part 2, Article 118) and from ten to fifteen years (Part 3, Article 118), while assault of person underage of fourteen, punishment is imprisonment from fifteen to twenty years (Part 4, Article 118). 
Objective aspect of assault according to edition 1959 of the Criminal Code consisted in sexual intercourse of male person with woman with the use of violence or threat of its use, as well as using helpless state of victim, i.e., with direct indication of victim gender. In 1994, with the adoption of new Criminal Code, content of objective aspect of this crime has transformed, the legislator has determined that in case of assault, person of both female and male sex can be recognized as a victim. In addition, in the specified period, new article 119 was introduced in the Criminal Code, which provides for liability for forcible satisfaction of sexual necessity in unnatural form, sodomy, committed against victim (without determining the sex).

Note that such notion of assault as a crime, the perpetrator of which, most commonly, is a man, and victim is a woman, is considered traditional both for doctrine of domestic criminal law and for the law enforcement practice. This circumstance plays important role in determining objective aspect of this type of crime, since physiologically sexual intercourse in a natural form, although against the will of person, with the use of violence and threats, is possible only against woman.

Article 119 of the Criminal Code establishes liability for unnatural cases, when actions of perpetrator are of a violent nature and they infringe on sexual freedom of person in unnatural form, whose gender does not matter for determining objective aspect of specified crime.

Thus, it can be stated that since liability for assault under Article 118 of the Criminal Code was established without taking into account physiological characteristics of person, and in order to protect rights of women in determining objective aspect of specified element of crime in this article, it is required to specify sex of person in whose respect sexual intercourse was done with the use of violence, threats or through his helpless state. At the same time, it should be recognized that existence of responsibility for assault (Article 118) in the modern Criminal Code and forcible satisfaction of sexual needs in an unnatural form, sodomy (Article 119), testifies the justice in the sense of equal criminal law protection of sexual freedom and sexual inviolability as for women and men. Thus, equality has been established in the protection of mentioned individual rights in the event of infringement on sexual freedom.

\section{CAMEROON PENAL CODE AND CRIMES AGAINST WOMEN}

Domestic violence is not recognized as a specific crime in Cameroon, and we don't have a legal definition of domestic violence. Cameroon does not have specific legislation by which domestic violence can be prosecuted; 
the criminal law is notoriously silent, and victims are left to rely on the general law of assault. Thus, acts of domestic violence can be prosecuted using the Cameroon's penal code under the following articles:

The Penal Code in its Article 278 states that no person is entitle to torture, physical and moral integrity, it also protects the right to life. It also states that serious injury cause by assault (Article 279), slight injury (Article 281), simple injury (Article 280) is punishable except in cases of selfdefense if provided by the law. The Penal Code also prohibits force marriages and penalized offender with imprisonment and a monetary fine Article 356 of the 1981 law. It also punishes sexual harassment from six months to one-year imprisonment and a fine of 100.000 francs, sexual assault from 5-10 years' imprisonment.

According to Article 293.1 of the Penal Code "(a) any person who reduces a person to or maintains a person in slavery, or (b) engages, even occasionally, in trafficking in human beings, shall be punished with imprisonment of ten to twenty years". Moreover, procuring is criminalized under Article 294 which provides that:

«1. Any person who causes, aids, or facilitates the prostitution of another individual or who shares, even occasionally, in the proceeds of the prostitution of another individual or receives subsidies from a person engaging in prostitution shall be punished with imprisonment of six months to five years and fine of 20.000 to 1.000.000 francs. 2. Any person who lives with an individual engaging in prostitution and who cannot provide proof of sufficient resources to enable him to provide for his own needs shall be presumed to be receiving subsidies».

Also, prostitution is a punishable offence. Article 343 states,

«1. Any person of either sex who habitually engages, for compensation, in sexual acts with others, shall be punished with imprisonment for six months to five years and a fine of 20.000 to 500.000 francs. 2. Any person who publicly recruits individuals of either sex through gestures, words, writings or any other means, for purposes of prostitution, or debauchery shall be punished with the same penalties».

Additionally, Article 292 criminalizes forced labor. It states that:

«Any person, who in order to satisfy his personal interests, imposes on another person any work or service obligation for which that person has not freely applied shall be punished with imprisonment of five to ten years and/or a fine of 10.000 to 500.000 francs».

The Cameroon Penal Code in its Section 293 provide that: "(a)Any person who reduces a person to or maintains a person in slavery, or (b) engages, even occasionally, in trafficking in human beings, shall be 
punished with imprisonment of ten to twenty years". Moreover, securing is at the level criminalizing which provide under Article 294 states that:

«1. Any person who causes, aids, or facilitates the prostitution of another individual or who shares, even occasionally, in the proceeds of the prostitution of another individual or receives subsidies from a person engaging in prostitution shall be punished with imprisonment of six months to five years and fine of 20.000 francs to 1.000 .000 francs. 2. Any person who lives with an individual engaging in prostitution and who cannot provide proof of sufficient resources to enable him to provide for his own needs shall be presumed to be receiving subsidies».

The notion of prostitution has not been left out, it considered as a punishable offence under the Cameroon Penal Code. Article 343 states:

«1. Any person of either sex who habitually engages, for compensation, in sexual acts with others, shall be punished with imprisonment for six months to five years and a fine of 20.000 francs to 500.000 francs. 2. Any person who publicly recruits individuals of either sex through gestures, words, writings or any other means, for purposes of prostitution or debauchery shall be punished with the same penalties».

The situation of force labor has not been exempted under the Code. Article 292 states that:

«Any person, who in order to satisfy his personal interests, imposes on another person any work or service obligation for which that person has not freely applied shall be punished with imprisonment of five to ten years and/or a fine of 10.000 francs to 500.000 francs».

Cameroon has ratified the ILO Convention on the Abolition of Forced Labor and the United Nations Supplementary Convention on the Abolition of Slavery, the Slave Trade, and Institutions and Practices Similar to Slavery. Cameroon signed the United Nations Protocol to Prevent, Suppress and Punish Trafficking in Persons, especially women and children, adopted by resolution A/Res/55/25, on 13 December 2000, but as of 9 October 2003 had not ratified it. OMCT notes with concern that it is the prostitute who is punished rather than the client who goes free. As many prostitutes do not prostitute themselves of their free will, they are doubly victimized through these punishments. 


\section{EXAMINATION OF SOME OF THE OFFENCES OF VIOLENCE ON WOMEN UNDER THE CAMEROON PENAL CODE}

The Cameroon Penal code has given room for a series of offences that can be consider as domestic violence and affects the status and rights of women within a given society. The offences are group in a particular order because they have common elements as they are committed through the use of force and intentional on someone. Even though with its varieties spelled out in the Penal Code, their mental elements that provoked them may not be the same.

\section{V.1. Assault Occasioning Death}

This offence under the Cameroon criminal law system is considered as an involuntary homicide which is punishable under Section 278 of the Cameroon Penal Code which provides that:

«1. Whoever by force or interference unintentionally homicide another's death shall be punished with imprisonment for from six to twenty years. 2 . Where the force or interference is used in the course of any act of witchcraft, magic or divination, the punishment shall be imprisonment for life».

Looking from the above offence prescribed, one can say that for someone to claim that violence was used on him or her, the must be the use of force or the aspect of interference. The perpetrator has committed a physical act as act cannot be done on the victim by mere omission. The perpetrator must have used any part of his body or even an object to hit the spouse who is complaining of violence, and such spouse must have felt the physical impact of the act. What we really need to note here is that the defendant act must have really resulted in the death of the spouse. There must really be a direct causal connection between the act of the husband and his spouse which is necessary to proof that the offence was committed. Let's take a critical example, there was a fight between a husband and a wife, the husband slapped the wife who suddenly collapses and was rushed to the hospital where the wife finally dies. The husband will be held criminally responsible for the wife death even though his wife was not to see his wife death.

Let's even say the act was not committed, because it is the role of the wife or spouse to prove that there was violence use on her by the husband. This can only be done with the presence of the intention which must be proven by the wife for it to amount to assault occasioning death. The 
observation of Lord Kenyon in Fowler v. Padget where he believes that in common parlance, it is a principle that must be prove by the wife that there was violence or assault on her by not only talking about the use of force that led to the death of the wife, but there must equally be the proof of the intention. The defendant needs not have intended the death of his spouse, so the presence of intention must be established. The provision of Section 74 of the Penal Code is clear when dealing with aspect assault occasioning death by providing that: "Criminal responsibility shall lie on him who intentionally commits each of the ingredient acts or omission of the offence with the intention of causing the result which completes it".

An observation under Section 278 of the Code is clear where its opine that the use of force or interference intentionally on the body of a spouse will amount to assault occasioning death, making the husband or defendant criminally liable and responsible for the act.

\section{V.2. Assault Occasioning Grievous Harm}

This is an offence that is handling by the Cameroon Penal Code in its Section 279 by establishing that:

«1. Whoever by force or interference unintentionally causes to another the injuries described in Section 277 of this Code shall be punished with the imprisonment for from five to ten years and in a fit case with fine of from five thousand to five hundred thousand. 2. Where use is made of a weapon of any explosive, corrosive or toxic substance, of poison or any other act of witchcraft, magic or divination, the imprisonment shall be from six to fifteen years».

It can be recalled and examine in this offence that, for there to be assault occasioning grievous harm the presupposes use of force or interference on the body of a spouse with the intention of depriving the spouse of the use of her whole or part of any member organ or sense will be enough. For an action to be brought against the husband for assault, the wife must proof that the husband force or interference resulted to the wife permanent loss of the use of her whole or any part of any member organ or sense. When we talk about member organs here, we are talking that the assault affected the wife organs like limb, leg or an arm; that is those organs of the wife body that carries out special function like the kidney, pancreas, liver or even the lung. As to the senses here, we are talking about the five sense or faculties of sight, smell, hearing, taste or touch each other enabling the wife to respond to stimuli. There must be serious harm or hurt on the person which affects or interferes with woman health or comfort. 


\section{V.3. The Situation of Simple and Slight Harm Caused on the Woman}

This is provided by Section 280 of the Penal Code which provides that:

«Whoever by use of force or interference causes intentionally or unintentionally to another any sickness or inability to work lasting more than thirty days shall be punished with imprisonment for from six months to five years or with fine of from 5.000 to 200.000 francs, or with both such imprisonment and fine».

For there to be proof of simple harm that is done on the wife, or spouse, the person must be able in establishing that there was a force or interference that was caused on her by the husband, and this resulted to sickness or inability to work which lasted for more than thirty days. There was the lack of skill, carelessness, rashness or even disregard of regulations which causes the wife harm, sickness or incapacity to work.

Regarding that of slight harm, the offence is punishable under Section 281 by providing that:

«Whoever by force or interference causes intentionally or unintentionally to another any sickness or inability to work lasting for more than eight days and up to thirty days shall be punished with imprisonment for six days to two years or with fine of from 5.000 to 50.000 francs or with both such imprisonment and fine».

Looking the two offences that is simple and slight harm, they are similar as the defendant must have use force or interference on the spouse who must have caused the spouse some sickness or inability to work for a number of days.

\section{V.4. Assault on Woman with Child}

This offence is handling in Section 338 of the Penal Code by providing that:

«Whoever by force used against a woman with child or against a child being born causes intentionally or unintentionally the death or permanent incapacity of the child shall be punished with imprisonment for from five to ten years and with a fine of from 100.000 to 2.000 .000 francs».

From the position established above, one can say that there must be the presupposes use of physical violence against a pregnant woman or even against a child being born. The physical violence used must produce a result which can either cause the death of the spouse or cause the spouse child permanently incapacitated. Here we are talking about the health of the child. 
The child can be born strong and healthy, but because of the physical violence that was done on the mother when pregnant, she continues to suffer from serious injuries resulting from the violent act of the husband. The husband cannot in any way deny this act as it is established that the physical force used by the husband produces the required result that the wife is suffering. The Cameroon Penal Code has offered great and special protection to a pregnant woman. Reference of this can be demonstrated in Section 22 of the Code which provides that: "No woman with child may be executed until after her delivery". This offence in question can lead or related to the offence of abortion of a woman with a child as it can be committed anytime from the conception of the baby to its delivery when it becomes an independent human being distinct from its mother. Section 337 of the Code reads: "Whoever procures the abortion of a woman, notwithstanding her consent, shall be punished with imprisonment for from one to five years and with fine of from one hundred thousand to two million francs".

It is therefore possible that the use of force on a pregnant woman with a baby can leads to abortion as specified in the case of assault on a woman with a baby. All these offences illustrated is just to show how our criminal code handles issues of violence on a woman.

\section{WOMEN VIOLENCE IS NOT PROSECUTED UNDER THE CAMEROON CRIMINAL LAW}

Violence in Cameroon is a pervasive problem. A 2004 study found that, of 2.570 women, $995(38.7 \%)$ reported physical violence and 381 (14.8\%) reported sexual violence. These data match more recent statistics, including a study from Douala-based La Maison des Droits de l'Homme that approximately 39 percent of Cameroonian women suffered from physical violence in 2008. These numbers indicate that little has been done to stem the epidemic of domestic violence in Cameroon in recent years. The vast majority of victims are female: $92 \%$ of domestic violence victims in Cameroon are women. Cameroon's Penal Code does not specifically criminalize domestic violence. Victims are thus left to rely on the general assault provisions in the Penal Code, which address murder (Articles 275 and 276), grievous harm (Article 277), assault causing death (Article 278), assault causing grievous harm (Article 279), simple harm (Article 280), failure to assist women abandoned by their husbands (Article 282), and assault of a pregnant woman (Article 338). In its National Report, the Cameroon Government asserts that domestic violence and spousal abuse 
will be "better expressed in the penal code currently under revision" and in the meantime, such crimes can be punished through "various classifications of injuries" under the existing legal framework, described above. But the process to prosecute these "injuries" under the current code is anything but clear in the context of domestic abuse. Cameroon asserted in its National Report that "with regard to punishment for spousal rape, any man who uses physical or moral violence to have sexual relations with a woman shall be punished by imprisonment for a term of five to 10 years". However, the United States State Department and reputable human rights organizations refute that statement, arguing that Article 296 of the Penal Code does not apply to spousal rape. In its National Report, Cameroon also indicated that:

«A husband who uses violence to force his wife to have sexual relations with him may be prosecuted for causing intentional injury, depending on the severity of the violence. All of this is a question of fact left to the discretion of the judge hearing the case of the victimized wife».

Further, rather than focusing on the lack of consent, criminal justice hinges on the presence of injury which may not be visible, present, documented, or difficult to prove. Based on these (potentially conflicting) statements, it is unclear as to what exactly the legal system provides in terms of enforcement against spousal rape and, more generally, domestic violence.

Moreover, victims of domestic abuse have little recourse for protection. There is no domestic violence law in Cameroon that provides women with an order for protection against abusers. The Family Code, was drafted in 1997 to address issues of domestic violence, has remained on the shelf, unadopted and unimplemented. Stakeholders see this failure to adopt the law as a lack of political will to address domestic violence. Women seeking to escape the violence through divorce are further hindered by the fact that spousal abuse is not a legal ground for divorce.

\section{WOMAN AS AN OBJECT OF CRIMES AGAINST FAMILY, YOUTH AND MORALITY}

In terms of analyzing crimes against women, we can consider criminal liability for polygamy (Article 126 of the Criminal Code). It should be noted that the Criminal Code of Uzbekistan in 1959 defined bigamy or polygamy as cohabitation with two or more women based on common household (Criminal Code of the Uzbek SSR, 1966), since then this element of crime has not undergone any special changes, the word «bigamy» is excluded from the name and disposition of specified content of the current Criminal Code. 
Main feature of objective aspect of this crime is cohabitation with two or more women based on common household. It seems that these actions, defined by legislator as «polygamy» go beyond the latter, since «polygamy» word means "being in official marriage with several wives at the same time" while "cohabitation is only life as a couple, living, sexual relationship between man and woman" (Ozhegov, 2014, p. 587), without official conclusion of marriage.

This gives reason to assume that legislator did not specify under what circumstances actions of guilty party are recognized as criminal: when guilty person is in official marriage relationship with two or more women, or when guilty party lives together (sexual relationships) with two or more women.

It seems that since, according to Article 16 of the Family Code of the Republic of Uzbekistan, marriage is not allowed between persons when at least one is already in another registered marriage, criminal liability is established not for polygamy (based on the context of this word), but for cohabitation-joint living with two or more women without formal marriage.

Similar disposition of criminal liability for cohabitation with two or more women can be found in the Criminal Codes of Tajikistan and Kyrgyzstan, at the same time, for example, the Criminal Code of Switzerland establishes liability specifically for polygamy: "those who conclude marriage being already married, who concludes marriage with a married person" (Article 215) is subject to criminal liability, while in Japan, Great Britain and Norway, polygamy, meaning as officially concluded several marriages, is also a criminal offense.

According to the Criminal Code of Poland, those who conclude marriage, despite the fact that they are already in marriage union, are prosecuted (Article 206), Article 192 of the Criminal Code of Austria stipulates liability for polygamy, i.e., to someone "who concludes new marriage while already in marriage or concludes marriage with a married person".

At the same time, criminal legislation of Azerbaijan, Kazakhstan, Russian Federation, Latvia does not contain criminal liability for polygamy at all.

In the process of studying crimes against women, particular interest aroused criminal liability for maintenance of house of prostitution (Article 131 of the Criminal Code). It should be noted that edition 1959 of the Criminal Code of Uzbekistan did not contain liability for indicated criminal acts, this article was introduced into the Criminal Code in 1999 and consisted of two parts, the first of which says that "Organization or maintenance of house of prostitution, as well as procuration motivated by money or other 
base motives", second part established distinctive features of this crime in the form of involving juvenile, repetition, dangerous recidivist or person who had previously committed crimes related to human trafficking or kidnapping.

Analysis of criminal legislation of foreign countries shows that concept of procuration includes prostitution, pimping, engaging in prostitution, etc. For example, the French Criminal Code's (2012) section «On procuration and identical criminal acts» determined that:

«Procuration is an act committed by any person in whatever form, expressed in: (i) Assisting, facilitating or encouraging prostitution of another person. (ii) Capitalizing on prostitution of another person, participating in distribution of income from this activity or receiving payments from person who systematically engages in prostitution. (iii) Involvement in prostitution, seduction or hiring for prostitution, or pressure on person to force him to engage in prostitution or continue to do so» (Article 2.255).

The Criminal Code of France determined distinctive features of this crime: making it easier for a pimp to legalize fictitious sources of his income, actions committed against juvenile, by ascendant, etc.

The Turkish Criminal Code contains «Incitement to prostitution», the independent chapter three, which defines liability of person who seduces and abets to prostitution a teenager under the age of 15 years, and creates conditions for this if the act of seduction was committed by one of the close relatives in ascendant, from among brothers or sisters, by adoptive parent, guardian or curator, teacher or tutor, servants or other persons under whose supervision the adolescent has been placed, and if a girl or woman who has reached the age of 21 is incited to prostitution by her husband, a close ascendant relative, brothers or sisters, etc. (Articles 420-426).

The Austrian Criminal Code's «Crimes against morality» section, establishes liability for procuring ( $\$ 213)$, facilitation of sexual abuse of others for money (\$214), assistance in professional prostitution (\$215), pimping (\$216). At the same time, for procuring, the one "who inclines a person to sexual abuse with another person with whom he is in relationship specified in $\$ 212$ (having parental rights), in the presence of prerequisites provided there, or inclines to sexual cohabitation", is subject to criminal liability. 


\section{CONCLUSION}

Concluding the article, we come to the following conclusions:

1. The issue of criminal liability for crimes against women in historical development was regulated by the legislation of Uzbekistan, and Cameroon while some elements of crime of forced nature did not determine gender of victim and criminal violence against women remained without due attention.

2. The current domestic legislations in these countries on crimes against women needs to be reformed. It is necessary to carefully review the elements of crimes where victim is a woman.

3. The rules of criminal law in terms of identifying features of legal regulation conditional with gender and family differences of subjects are subject to careful analysis, since the content of criminal law rules is not sufficiently socially conditioned.

4. It should be summarized that since the criminal legislation is the finalizing element in the legal system of the state, it must contain all the grounds for occurrence of the most severe type of legal liability: the criminal liability for crimes against women. 


\section{REFERENCES}

Cameroon (2016). Penal Code of the Republic of Cameroon [Law No. 2016/007]. July 12, 2016.

Kaukinen, K. (2020). When Stay-At-Home Orders Leave Victims Unsafe at Home: Exploring the Risk and Consequences of Intimate Partner Violence During the Covid-19 Pandemic. American Journal of Criminal Justice, 45, 668-679. Doi: https://doi.org/10.1007/s12103-020-09533-5

Lebedev, V. M. (2013). Commentary on the Criminal Code of the Russian Federation. Urait.

Lehenka, M. M. (2018). International Experience in Combating Domestic Violence and the Possibilities of Its Implementation in Ukraine. Law \& Safety, 67 (4), 111116.

Morgan, A., Boxall, H., Dowling, C., \& Brown, R. (2020). Policing Repeat Domestic Violence: Would Focused Deterrence Work in Australia. Australian Institute of Criminology, 593.

Orlov, Y. V. (2020). Problems of Criminal and Legal Qualification of Domestic Violence. Law \& Safety, 79 (4), 13-19. https://doi.org/10.32631/pb.2020.4.01

Ozhegov, S. I. (2014). Slovap Russkogo Iazika [Dictionary of the Russian Language]. Azbukovnik.

State Statistics Committee of the Republic of Uzbekistan (2019). Socio-economic Situation of the Republic of Uzbekistan [XVII. Offenses]. https://stat.uz/ru/164ofytsyalnaia-statystyka-ru/6575-prestupnost2

Supreme Court of the Republic of Uzbekistan (2014). Collection of Resolutions of Plenums of the Supreme Court of the Republic of Uzbekistan. Adolat.

Suyunova, D. J. (2021). Improvement of Criminal Law Measures to Prevent Violence Against Women. Eurasian Law Journal, 153 (2), 262-264. Doi: 10.46320/2073-4506-2021-2-153-262-264

Suyunova, D. J., \& Acharya, B. (2021). Prospects for the Institution of Preliminary Hearing in Uzbekistan. The American Journal of Political Science Law and Criminology, 3 (2), 139-143. Doi: 10.37547/tajpslc/Volume03Issue02-20

Suyunova, D. J., \& Shamsutdinov, B. (2021). Digitalization of Criminal Proceedings in the Context of the Coronavirus Pandemic (Covid-19) in Uzbekistan. MedicoLegal Update, 21 (2), 455-459. Doi: https://doi.org/10.37506/mlu.v21i2.2723

Taub, A. (14-IV-2020). New Covid-19 Crisis: Domestic Abuse Rises Worldwide. New York Times. https://www.nytimes.com/2020/04/06/world/coronavirus-domesticviolence.html

Turkey (2004). Turkish Criminal Code [Law No. 5237]. September 26, 2004.

United Nations (1979). Convention on the Elimination of All Forms of Discrimination Against Women. December 18, 1979. 
Uzbekistan (1966). The Criminal Code of the Uzbek SSR.

Uzbekistan (1988). The Criminal Code of the Uzbek SSR.

Uzbekistan (2019). The Criminal Code of the Republic of Uzbekistan. 